\title{
Differential effects of defoliation by mopane caterpillars and pruning by African elephants on the regrowth of Colophospermum mopane foliage
}

\author{
Halszka Hrabar, ${ }^{*}$, Dawood Hattas $\dagger$ and Johan T. du Toit*, $\ddagger$ \\ * Mammal Research Institute, Department of Zoology and Entomology, University of Pretoria, Pretoria, South Africa \\ $\dagger$ Department of Botany, University of Cape Town, Private Bag X3, Rondebosch, 7701, Cape Town, South Africa \\ $\ddagger$ Department of Wildland Resources, Utah State University, Logan, UT 84322-5230, USA \\ (Accepted 24 January 2009)
}

\begin{abstract}
Plant responses to herbivory vary depending on herbivory type, yet the comparative effects of defoliation (e.g. by insects) and pruning (e.g. by large mammals) on a single tree species are poorly documented. We investigated this in the Northern Province of South Africa by comparing the regrowth of Colophospermum mopane trees previously defoliated by caterpillars or pruned by elephants, the two main browsers of C. mopane foliage. Shoots were up to $160 \%$ and $125 \%$ longer after natural (elephant) and simulated pruning and leaves $\sim 25 \%$ longer in regrowth after natural pruning ( $\mathrm{n}=13-15$ trees per treatment). Shoot density and chemical defences in leaves (tannin:protein ratio and total polyphenolic concentration) were, however, no different from control trees. Simulated defoliation resulted in statistically insignificant changes to regrowth in terms of leaf and shoot size (both slightly decreased) and shoot density (slightly increased). Natural (caterpillar) defoliation, however, resulted in regrowth with significantly decreased shoot and leaf size (about $50 \%$ and $20 \%$ of control lengths, respectively), as well as decreased leaf chemical defence. Shoot and leaf length were longer on trees flushing for the first time after pruning and late-season defoliation had a greater negative impact than mid-season defoliation. Despite the differences in regrowth characteristics after pruning and defoliation, mopane plants showed no apparent trade-off in investment between tolerance and resistance after either herbivory type, as neither regrowth nor chemical defence occurred at the expense of the other.
\end{abstract}

Key Words: herbivore-plant interactions, Imbrasia belina, Loxodonta africana, resistance, savanna ecology, tolerance

\section{INTRODUCTION}

A key factor determining a woody plant's response to browsing is the type of damage inflicted, namely, shoot/branch/stem damage such as by mammalian browsers (hereafter referred to as 'pruning'), versus leaf consumption such as by folivorous insects (hereafter referred to as 'defoliation'). Severe pruning tends to result in an increase in the growth rate of the remaining or resprouting shoots (Messina et al. 2002), the production of fewer but longer shoots with larger leaves (Bergström et al. 2000, Danell et al. 1994, Duncan et al. 1998, Lehtilä et al. 2000), and reduced chemical defence (du Toit et al. 1990). Severe defoliation, however, tends to result in regrowth with smaller shoots and leaves (Anttonen et al. 2002, Gadd et al. 2001, Piene et al. 2003, Rooke

\footnotetext{
${ }^{1}$ Corresponding author. Email: hhrabar@zoology.up.ac.za
}

\& Bergström 2007) and a variety of adjustments in foliar chemical composition (Bryant et al. 1991). The variability in responses suggests that plants have adapted different strategies to deal with each type of browsing, with a tolerance response to pruning and a more complex response of both tolerance and resistance to defoliation.

While numerous studies have investigated plant responses to variation in the intensity, frequency and timing of pruning or defoliation (Lennartsson et al. 1998), few studies have made comparisons between pruning and defoliation within an individual tree species. We consider this to be an important gap in research into browser-woody plant interactions because comparisons between plant responses to different browsing types are confounded by differences between functional types of host plants (e.g. at the most basic level, deciduous versus evergreen; Krause \& Raffa 1996). By focusing on a single plant species, we aimed to improve our understanding of the differential effect each browsing type has, and 
Colophospermum mopane Kirk ex J. Léonard (commonly known as mopane) provides the opportunity to carry out such an investigation in a natural system. This deciduous, xeric savanna woodland species is well known for its suite of chemical defences and dominates the plant community over vast areas of southern Africa. Due to its resistance to most herbivores, it is a significant food resource for only two browsers - mopane caterpillars (larvae of the emperor moth Imbrasia belina Westwood, 1849) and African elephants (Loxodonta africana Blumenbach, 1825).

Our study aimed to compare influences of defoliation by mopane caterpillars and pruning by elephant on $C$. mopane regrowth and represents a novel investigation into how a megaherbivore and an insect interact through their shared resource, which is unprecedented in browsing guild research. We specifically tested the following hypotheses: (1) no quantitative differences (structural and chemical) exist in the regrowth of C. mopane following caterpillar defoliation versus elephant pruning; (2) timing of caterpillar defoliation (early versus late season) does not affect regrowth; (3) the frequency of caterpillar defoliation (once versus twice) does not affect regrowth; (4) the first flush of regrowth after caterpillar defoliation and elephant pruning does not differ to the second flush i.e. the following season.

\section{METHODS}

\section{Study site}

The study was carried out in the Venetia-Limpopo Nature Reserve, situated in the Northern Province of South Africa $\left(22^{\circ} 08^{\prime}-27^{\prime} \mathrm{S}, 29^{\circ} 13^{\prime}-28^{\prime} \mathrm{E}\right)$. It is fenced, 34500 ha in extent, and the vegetation of the region is classified as 'Mopane Veld' (Acocks 1975). The area has flat topography with sandstone underlying deep $(>2 \mathrm{~m})$ colluvial soils.

The study area is characterized by a wet, hot period between October and December (monthly mean maximum $32{ }^{\circ} \mathrm{C}$ ) and is dry and mild during mid-year months (monthly mean maximum $24.7^{\circ} \mathrm{C}$ in June). The mean annual rainfall for Pontdrift, about $15 \mathrm{~km}$ from the reserve, is $366 \mathrm{~mm}(1967-1997)$ with a $36 \%$ coefficient of variation. Rainfall usually occurs between October and March with a peak in January (Smit \& Rethman 1998).

From the 1940s the land was used for livestock ranching. Farms were heavily stocked with cattle and goats, resulting in soil and vegetation degradation (MacGregor \& O'Connor 2002). Livestock were then removed between 1981 and 1996 while the area was being consolidated as a private nature reserve. Indigenous herbivores were reintroduced in 1989-1991, including 43 elephants in 1993 and 1994. The elephant population, which is now estimated to be at 60 , is still at a relatively low density $\left(0.17\right.$ animals $\left.\mathrm{km}^{-2}\right)$ compared to other populations within mopane woodland (e.g. 1.1 elephants $\mathrm{km}^{-2}$ in Luangwa Valley, Zambia; Lewis 1991).

\section{Study species}

Colophospermum mopane can form the dominant constituent of the elephant diet within certain areas (Lewis 1991, Smallie \& O'Connor 2000), which can become heavily impacted by elephants (Ben-Shahar 1993). Smallie \& O'Connor (2000) found that for shrub-height individuals, the preferred size by elephants, browsing was mainly of branches, foliage and/or the main stem, while bark stripping was mainly from trees $>4 \mathrm{~m}$ high. Elephants therefore have a pruning effect on mopane trees and even though, on average, individual mopane trees are only lightly utilized, stem breakage can result in the loss of $51-75 \%$ of above-ground biomass, and the occurrence of such utilization is known to increase under conditions of limited resources (caused by drought, high elephant densities etc.). Additionally, elephants have a preference for rebrowsing mopane trees with a greater availability of the preferred branch size resulting from damage-induced coppicing (Smallie \& O'Connor 2000). The recurrent breakage of branches and stems, together with continuous browsing of foliage (hedging), can therefore maintain certain mopane stands under a regime of chronic browsing.

Imbrasia belina (family: Saturniidae) is widespread in southern Africa, tropical and East Africa, occurring from semi-desert to savanna and thick bush. The larvae feed on a number of tree species, yet large outbreak populations only follow that of their main host plant, C. mopane (Pinhey 1972). Adult moths emerge from their 6-8-mo pupation in response to rainfall and females lay a single cluster of 30-335 eggs on the host tree (Ditlhogo 1996). During their 6-wk larval stage, mopane caterpillars undergo a 4000-fold increase in body mass and reach a length of about $80 \mathrm{~mm}$ (Gaston et al. 1997). During this phase, large stands of trees are completely defoliated. Additionally, while population numbers may vary quite considerably from year to year, under favourable conditions (sufficient rainfall etc.) two brood sessions can take place within one wet season, first in November-December and again in February-March. Trees may hence undergo complete defoliation twice within a single growing season and this cumulative effect of defoliation events (Kaitaniemi et al. 1999, Strauss 1991), together with the differential timing of leaf herbivory (Tiffin 2002), is expected to have a significant effect on mopane regrowth responses. 


\section{Treatment transects}

Six 80-m transects were set out within a flat and uniform area of mopane woodland, with a mean tree height of $2.17 \mathrm{~m}(\mathrm{SD}=0.637, \mathrm{n}=144)$. Three transects were on each side of the road at 100-m intervals; positioned parallel, perpendicular, and at $45^{\circ}$ to the road. The first three transects ran consecutively on one side of the road and the next three followed on the other side. The starting point of each transect was $10 \mathrm{~m}$ from the road. Along each transect, a tree was marked every $20 \mathrm{~m}$ with a metal tag nailed into its base (five trees per transect, i.e. $\mathrm{n}=30$ ). Around each marked tree, six additional trees, positioned roughly $60^{\circ}$ apart and 2-8 $\mathrm{m}$ away from the central tree, were marked. Trees of similar size and with minimal evidence of prior elephant browsing were chosen. Each group therefore consisted of seven trees. This orderly layout of experimental trees was necessary to ensure they could be found again in the dense, homogeneous C. mopane woodland.

In August 2002, at the time of year when utilization of woody plant parts by elephants is highest (Lewis 1986), one tree from each tree group was subjected to simulated elephant browsing. Stems and branches were broken off at 1-1.5 $\mathrm{m}$ (the preferred browsing height of elephants; Smallie \& O'Connor 2000), until about 75\% of the original biomass was removed. In August 2003 the same treatment was applied to a second tree in each group.

To simulate the two successive mopane caterpillar defoliation events, one tree in each group was artificially defoliated in November 2002; one in February 2003; one in November 2002 and again in February 2003; and one in November 2003. Trees were at least 90\% defoliated by removing the entire leaf lamina by hand while leaving the leaf petiole, to best mimic caterpillar defoliation. The seventh tree in each group was left as a control. Treatments to simulate natural pruning (elephant) and defoliation (caterpillar) were applied and labelled as follows: elephant 2002 (E02); elephant 2003 (E03); caterpillar November 2002 (CNO2); caterpillar February 2003 (CF03); caterpillar November 2002 and February $2003(\mathrm{CN}+\mathrm{F})$; caterpillar November 2003 (CNO3); control (Con).

The validity of using simulated herbivory can be dubious (Baldwin 1990, Tiffin \& Inouye 2000) except (1) when used to evaluate the direct effects of herbivory on basic plant processes such as growth, reproduction and general physiological responses (e.g. plant allocation to secondary compounds and changes in nutrient concentrations), and (2) for insect herbivores that inflict well-defined damage to plants that is easy to mimic with accuracy, such as external leaf-feeding insects (Hjältén 2004). Our study fulfilled both these requirements and simulated herbivory has a number of advantages for studies such as ours that require the ability to control the magnitude and timing of damage and to avoid bias resulting from biotic and abiotic effects.

There are nevertheless certain unavoidable differences between natural and simulated herbivory that need to be borne in mind. For example, simulated defoliation took a maximum of $2 \mathrm{~h}$ per tree, while naturally it would be a continuous process over about $3 \mathrm{wk}$. Also, some insect herbivores have been found to alter plant physiology by injecting salival components while feeding (Alborn \& Turlings 1997, McCloud \& Baldwin 1997) and the same has been found for mammalian browsers such as moose Alces alces (Bergman 2002) and domestic goats Capra hircus (Rooke 2003). Lastly, urine and faeces of mammals and insects can have a strong effect on soil processes (nutrient recycling), which can then influence plant communities (Hobbs 1996, Reynolds \& Hunter 2001).

\section{Natural browsing by mopane caterpillars and elephants}

To check the reliability of the simulation results, the effects of natural elephant and caterpillar browsing were also assessed. In January 2004, when an outbreak of mopane caterpillars had just taken place, three transects were set out within defoliated areas. Along each transect, five defoliated trees were marked and for each of these, the nearest non-defoliated mopane tree of similar size was marked as the tree's partner (total $\mathrm{n}=15$ for each 'utilization'). An area with a high degree of elephant browsing was also identified and 13 elephantpruned trees were marked, along with 13 non-pruned partners.

\section{Measuring regrowth and foliar chemical composition}

In November 2003, an unpredicted outbreak of puss moth caterpillars (Family: Notodontidae, Genus: Epicerura; Picker et al. 2002) defoliated most trees along three of the six treatment transects. These transects were therefore excluded from the experiment, reducing the transects to three, with a total of 15 trees per treatment.

In February 2004 the trees in each treatment were revisited and the following variables were measured: leaf size, shoot length, shoot density and foliar chemical composition. Leaf length was used as an indicator of leaf size (as leaf length and width are correlated; Hrabar 2005), measured (in $\mathrm{mm}$ ) from the growth point to the tip of the right leaflet. Fifteen mature undamaged leaves were measured for each tree and were chosen randomly from all sides of the canopy, between a height of $0.5-2 \mathrm{~m}$. The length of the current year's growth (which was clearly identifiable) was measured for 15 shoots per tree, to the 
nearest $\mathrm{cm}$. Shoot density was measured as the number of shoots on the terminal $50 \mathrm{~cm}$ of a branch, for five branches per tree.

To determine foliar chemical composition, mature leaves were collected randomly from around the canopy of each tree. Leaves were first air dried in brown paper bags and later oven dried at $50{ }^{\circ} \mathrm{C}$ for at least $4 \mathrm{~d}$. Samples were then milled through a 1-mm screen. Crude protein concentration was determined according to the Dumas method (AOAC 1990). Total phenols and condensed tannins were analysed in accordance with Hagerman (1995). Total phenols were quantified using the Prussian blue assay for total phenols and condensed tannins were assayed using the acid butanol method for proanthocyanidins. Dried leaf material $(\sim 0.05 \mathrm{~g}$ per sample) was extracted with $3 \mathrm{ml}$ of $70 \%$ aqueous acetone by sonicating in an ice-water bath for $30 \mathrm{~min}$ and centrifuging at $2000 \mathrm{~g}$ for $10 \mathrm{~min}$. A $0.1-\mathrm{ml}$ aliquot of the supernatant was used in both assays. Sorghum tannin that was previously extracted and purified as described in Hagerman (1995) was used as the condensed tannin standard while gallic acid was used to standardize total phenols. Total phenols and condensed tannin quantities were calculated as $\mathrm{mg} \mathrm{g}^{-1} \mathrm{DW}$ (dry weight), while protein was calculated as the percentage of DW.

We appreciate that chemical composition values obtained in this study are not absolute leaf concentrations, as these were not possible to obtain with the field methods used. Samples should ideally have been frozen in liquid $\mathrm{N}$ and freeze-dried, instead of being air dried, but this was not possible due to limited facilities in the field. Values were, however, used only as relative measures for comparative purposes within the study, and are therefore suitable for this purpose. A detailed chemical analysis of secondary metabolites was not in the scope of this project, especially since mopane is well known for its complex chemical make-up (Ferreira et al. 2003). Secondary metabolites such as tannin, which accumulate in high concentrations and are often stable end products, are most likely to be directly correlated with total allocation to secondary metabolites (Herms \& Mattson 1992). Additionally, carbon-based secondary compounds such as phenols and tannins have been considered the most general chemical defences of woody plants against herbivores for more than three decades (Feeny 1970).

In March 2004, once the regrowth on the naturally defoliated trees had stopped growing (see Hrabar 2005), all browsed (elephant and caterpillar) and partnering non-browsed trees were revisited and information on the current year's growth recorded. Leaf size, shoot length and shoot density were measured as described above. Leaf samples were also collected for chemical analysis.

\section{Statistical analysis}

For simulated treatments, we first tested whether there was significant variation in the regrowth (shoot length, leaf length, shoot number per $50 \mathrm{~cm}$, and foliar tannin:protein ratio and polyphenolic concentration) across the three transects, using Kruskal-Wallis ANOVA. Similarly, due to the data not being normally distributed, Kruskal-Wallis ANOVA was used to test for significant variation in responses to the seven treatments, for each response variable individually. Where significant variation was detected, multiple comparison tests were used to determine which treatments were responsible.

Data from the naturally utilized trees were also not normally distributed, so Wilcoxon matched-pairs tests were used to test for differences between the regrowth on elephant-pruned trees and non-pruned trees, and between caterpillar-defoliated trees and non-defoliated trees (Zar 1999). All statistical analyses were conducted using STATISTICA (StatSoft, Tulsa, Oklahoma, USA).

\section{RESULTS}

\section{Simulated treatments}

There was no significant variation across the three treatment transects (those undamaged by puss moth caterpillars) with respect to any of the regrowth characteristics. We therefore assumed no 'transect' effect and grouped the trees from all three transects for analyses.

Simulated treatments had a significant effect on shoot length (Kruskal-Wallis ANOVA: $\chi^{2}=42.0, \mathrm{df}=6$, $\mathrm{P}<0.01)$ and leaf length $\left(\chi^{2}=28.4, \mathrm{df}=6, \mathrm{P}<\right.$ 0.01 ). Shoots and leaves were significantly longer on pruned trees than defoliated trees (except $\mathrm{CNO} 3$ trees, Figure 1). Leaves were longest on E03 trees, which were $27 \%$ longer than leaves on $\mathrm{CN}+\mathrm{F}$ trees (the shortest leaves). The decrease in leaf length on defoliated trees and the increase in length on pruned trees was, however, not significant when compared with control trees.

Only trees flushing for the first time since pruning (E03 trees) had shoots significantly different from control-tree shoots, and these shoots were also significantly longer than shoots on pruned trees flushing for the second time (E02 trees). This increase in shoot length was double on first-flush E03 trees compared with the second-flush E02 trees $(126 \%$ and $58 \%$ longer than control tree shoots respectively). Although the difference was not significant, trees defoliated in February tended to have slightly shorter shoots and leaves than trees defoliated in November. Lateseason defoliation therefore appears to have the greatest negative impact on regrowth in mopane.

Shoot number tended to increase after defoliation treatments, but not significantly (Kruskal-Wallis 

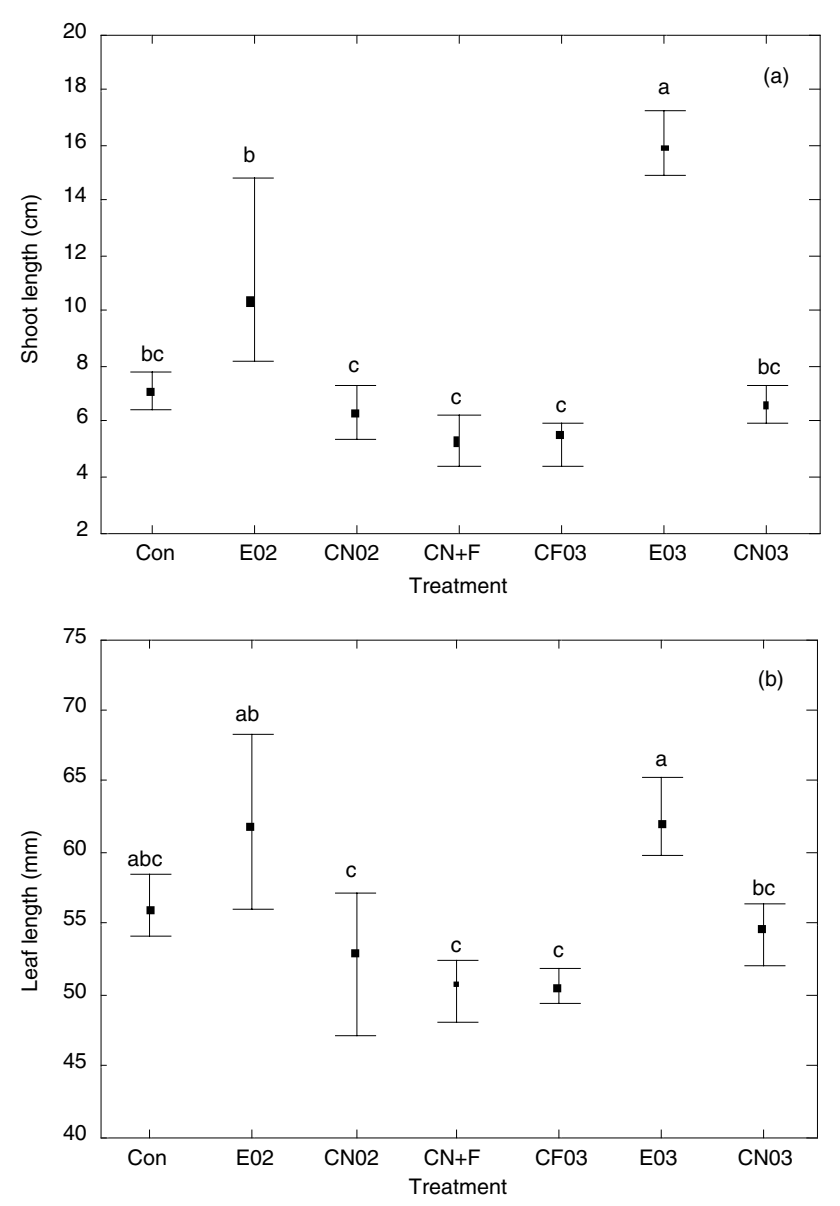

Figure 1. A comparison of the effects of various elephant pruning and caterpillar defoliation treatments on shoot length (a) and leaf length (b) of Colophospermum mopane regrowth (median and interquartile range). Treatments included: simulated elephant pruning in August 2002 (E02) and August 2003 (E03); simulated caterpillar defoliation in November 2002 (CNO2), February 2003 (CFO3), November 2002 and February $2003(\mathrm{CN}+\mathrm{F})$, and November 2003 (CNO3), as well as controls (Con). All regrowth data were collected in February 2004. Different letters above bars indicate significant differences between treatments.

ANOVA: $\left.\chi^{2}=12.2, \mathrm{df}=6, \mathrm{P}=0.057\right)$. Furthermore, there was no significant difference in the tannin:protein ratio or total polyphenolic concentration of the foliage $\left(\chi^{2}=3.59, \mathrm{df}=6, \mathrm{P}=0.732 ; \chi^{2}=2.00, \mathrm{df}=6, \mathrm{P}=\right.$ 0.92 respectively, Table 1$)$.

\section{Naturally browsed trees}

Regrowth on trees naturally pruned by elephants was similar to the simulated treatment trees. Shoots and leaves were significantly longer than on non-pruned trees (Wilcoxon matched-pairs t-test: $\mathrm{T}=0$ and 2 respectively, $\mathrm{P}<0.01$ ), while there was no difference in the number of shoots per $50-\mathrm{cm}$ length of branch $(\mathrm{T}=31, \mathrm{P}=0.859)$, nor in the tannin:protein ratio and total polyphenolic concentration of the foliage $(\mathrm{T}=36, \mathrm{P}=0.507 ; \mathrm{T}=29$, $\mathrm{P}=0.249$ respectively; Figure 2 and Table 1 ).

Natural caterpillar defoliation, however, had a greater effect on plant responses than simulated defoliation. Both shoot and leaf lengths were significantly shorter on previously defoliated trees than non-defoliated trees (Wilcoxon matched-pairs test: $\mathrm{T}=0$ and 1 respectively, $\mathrm{P}<0.01$ ) and foliar tannin:protein ratio and total polyphenolic concentration were significantly reduced (Wilcoxon matched-pairs test: $\mathrm{T}=19$ and 17 respectively, $\mathrm{P}<0.05$; Figure 2). Only shoot density was unaffected $(\mathrm{T}=38, \mathrm{P}=0.211)$.

The difference in length of leaves on pruned trees compared with non-pruned trees $(26 \%$ increase) was similar to the difference between leaves on defoliated and non-defoliated trees (21\% decrease). Shoot length on pruned trees was, however, $160 \%$ greater than on nonpruned trees, while shoots on defoliated trees were only $47 \%$ shorter than on non-defoliated trees.

\section{DISCUSSION}

Both mopane caterpillars and elephants cause extensive damage to individual mopane trees, yet our study revealed that the two types of herbivory affect plant regrowth in significantly different ways. We therefore reject the null hypothesis that no quantitative differences in regrowth occur after caterpillar defoliation versus elephant browsing. Both simulated and natural pruning by elephants resulted in the production of longer shoots and leaves, while defoliation by caterpillars had the opposite effect. Foliar chemical composition was only found to change after natural caterpillar defoliation, with reduced chemical defence in the regrowth. These lower chemical defences are unlikely to be due to caterpillars avoiding trees with high chemical defences, as Hrabar (2005) found host leaf chemistry had no influence on host choice by ovipositing female moths.

The differential effects of pruning and defoliation on regrowth structural characteristics is consistent with results from several other studies on browsing (Bryant et al. 1991, Danell et al. 1994, Lehtilä et al. 2000). The high intensity of branch and stem breakage from pruning had a significant impact on the root/shoot ratio, as up to $75 \%$ of the canopy biomass was removed. When part of the photosynthetic material of a plant is removed, potentially more water and nutrients are available for the remaining photosynthetic material, resulting in increased shoot and leaf growth (Alados et al. 1997). However, the root/shoot ratio is unaffected by defoliation, which explains the increase in shoot and leaf size after pruning, but not defoliation. Similarly, in this study, the shorter shoot length on trees flushing for the second time after pruning (E02) compared to those flushing for the first time 
Table 1. Foliar chemical composition of Colophospermum mopane leaves (mean \pm SE) after simulated and natural elephant and mopane caterpillar browsing. Refer to Figure 1 legend for treatment code details.

\begin{tabular}{lccc}
\hline Herbivory type & Protein (\% of DW) & $\begin{array}{c}\text { Condensed tannins } \\
\left(\mathrm{mg} \mathrm{g}^{-1} \mathrm{DW}\right)\end{array}$ & $\begin{array}{r}\text { Total phenols } \\
\left(\mathrm{mg} \mathrm{g}^{-1} \mathrm{DW}\right)\end{array}$ \\
\hline Simulated treatments & $18.2 \pm 0.56$ & $57.6 \pm 4.62$ & $48.5 \pm 3.57$ \\
$\quad$ E02 & $16.7 \pm 0.60$ & $65.0 \pm 3.17$ & $52.9 \pm 2.10$ \\
CNO2 & $16.4 \pm 0.29$ & $54.5 \pm 3.80$ & $45.7 \pm 2.79$ \\
CN+F & $16.9 \pm 0.54$ & $53.9 \pm 3.11$ & $46.4 \pm 1.96$ \\
CF03 & $17.5 \pm 0.37$ & $60.5 \pm 2.60$ & $47.1 \pm 1.50$ \\
E03 & $17.5 \pm 0.32$ & $59.0 \pm 2.98$ & $50.6 \pm 1.89$ \\
CN03 & $16.9 \pm 0.50$ & $57.3 \pm 2.62$ & $48.9 \pm 1.69$ \\
Con & & & \\
Natural elephant browsing & $17.8 \pm 0.54$ & $83.9 \pm 3.87$ & $61.0 \pm 3.26$ \\
$\quad \begin{array}{l}\text { Pruned } \\
\quad \text { Non-pruned }\end{array}$ & $16.3 \pm 0.41$ & $81.4 \pm 3.86$ & $66.0 \pm 2.63$ \\
Natural caterpillar browsing & & & \\
$\quad$ Defoliated & $20.2 \pm 0.25$ & $69.9 \pm 5.35$ & $52.4 \pm 3.67$ \\
$\quad$ Non-defoliated & $16.5 \pm 0.40$ & $72.3 \pm 3.40$ & $63.9 \pm 3.39$ \\
\hline
\end{tabular}

(E03) can be explained in this way, as the root/shoot ratio would have decreased after the first flush. We therefore reject the null hypothesis that there is no difference in postpruning regrowth between the first and second flushes.

Interestingly, leaf length on trees defoliated in November 2002 tended to be smaller than on trees defoliated in November 2003, yet changes in root/shoot ratio did not occur. On the contrary, the impact of defoliation is expected to decrease with time as stored resources are replenished. An explanation here could be the exceptionally low late-season rainfall experienced after the November 2002 defoliation. Growth of mopane requires soil moisture (Henning \& White 1974) and trees defoliated in February 2003 were unable to flush again that season, yet in the following season (2003-2004), which experienced good rainfall into March, stands of trees were observed to re-flush each time after three complete defoliation events (once was by puss moth larvae). Furthermore, despite the inability to reflush after the February 2003 defoliation, late-season defoliation had less of a negative impact (not significantly different to early season defoliation) on regrowth the following growing season than expected (compared with studies by: Danell et al. 1994, Lennartsson et al. 1998, Maschinski \& Whitham 1989, Tiffin 2002). We therefore accept the null hypothesis that regrowth is not affected by timing of defoliation. Our study suggests that tolerance (i.e. regrowth) of mopane to herbivory is soil moisture dependent.

Also contrary to expectation, defoliation frequency did not affect the regrowth on treatment trees in this study. Colophospermum mopane trees are therefore able to display equal tolerance to one or two defoliation events in a single season and our defoliation-frequency hypothesis cannot be rejected here. A longer history of defoliation could, however, cause a significant negative affect on C. mopane.
The reduction in regrowth on naturally defoliated trees compared with non-defoliated trees could, for example, be due to such a history as they are likely to have been selected for in the past.

Despite the differences in regrowth after defoliation and pruning, neither type of herbivory appeared to result in a trade-off in investment between tolerance and resistance. After simulated defoliation treatments, for example, regrowth appeared to be no different in quantity (any decreases from slightly smaller shoots and leaves would most likely have been made up for by the increase in shoot number) or chemical composition (tannin:protein ratio) to that of non-defoliated trees. Trees thus displayed traits for both tolerance and resistance. Similarly, despite the increased size of individual shoots and leaves after pruning (both simulated and natural), investment in chemical defence was no different from unpruned trees, indicating an ability of mopane to maintain a simultaneous investment in both tolerance and resistance, irrespective of damage type.

This apparent lack of trade-off in investment is also supported by the regrowth characteristics of naturally defoliated trees in this study. Here, the decrease in leaf and shoot size was accompanied by a simultaneous decline in chemical defences. Furthermore, while the effect of natural pruning by elephant was similar to simulated pruning in this study, Hrabar (2005) found a negative impact on both regrowth (no increase in leaf size such as this study) and chemical defences (decreased tannin:protein ratio) from elephant browsing of mopane trees in the Kruger National Park. This shows that even when stored resources appear to be limited, the reduced investments in growth and chemical defence still do not take place at the expense of each other.

One explanation for this lack of trade-off could be that in a monospecific stand of unpalatable mopane trees, 

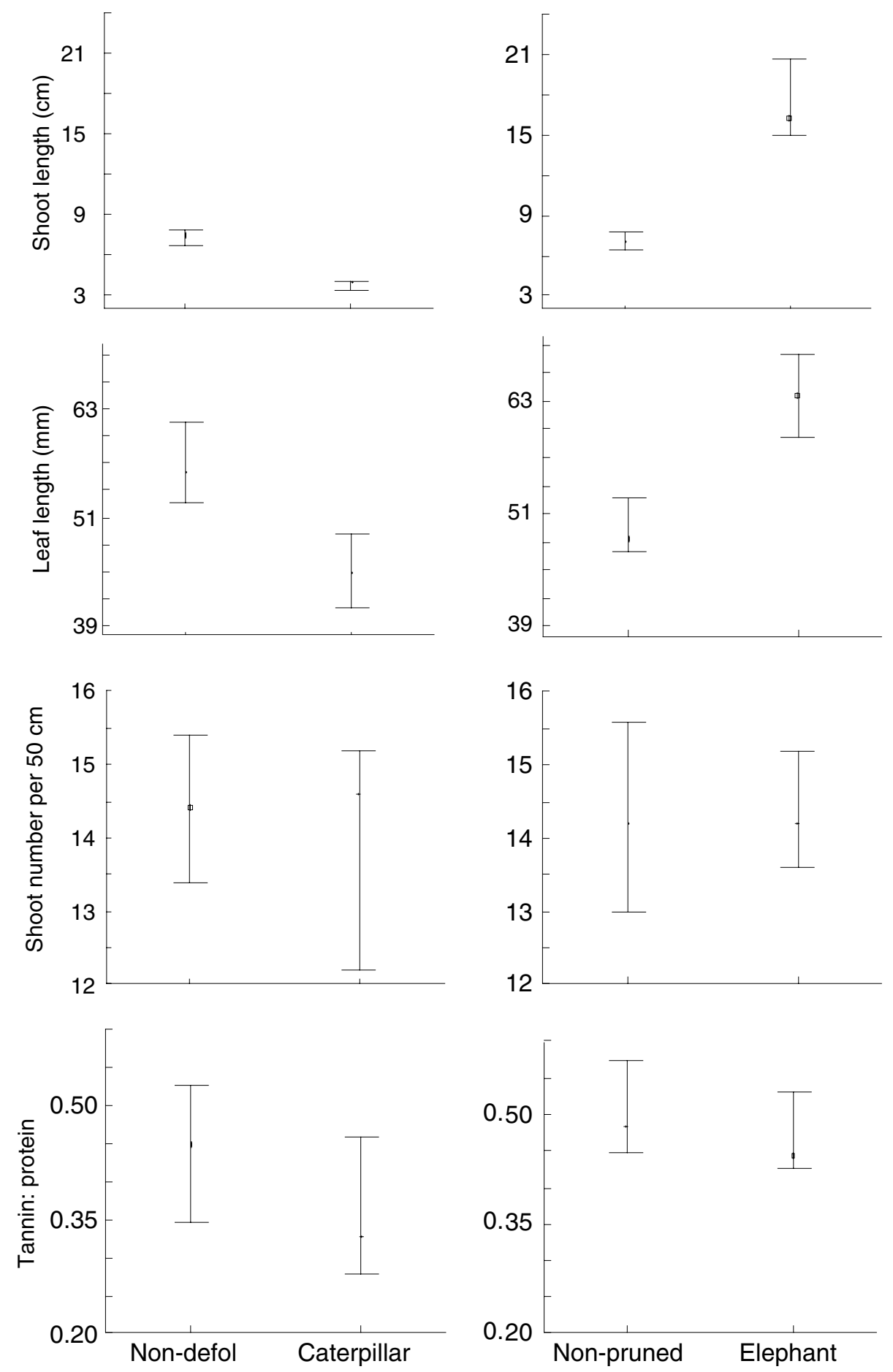

Figure 2. Shoot length, leaf length, shoot density and leaf tannin:protein ratio of regrowth on Colophospermum mopane trees naturally pruned by elephants and defoliated by mopane caterpillars, in comparison to shoot and leaf characteristics on neighbouring non-pruned/defoliated trees (median and interquartile range).

any decrease in defence could attract selective browsing of those trees by herbivores that do not usually feed on mopane. Alternatively, mopane trees might simply have excess carbon stores available for the production of carbon-based defences, at little cost to the plant. The nutrient-poor and drought-prone conditions in which it grows (Timberlake 1995) are likely to constrain growth more than photosynthesis, resulting in assimilates in excess of growth requirements being available for defence (Herms \& Mattson 1992). Katjiua \& Ward (2006) found 
this exact relationship between resource availability (soil nutrients and moisture availability) and the tradeoff in investment between resistance and tolerance for Terminalia sericea trees, where no trade-off was found in resource-poor environments.

In conclusion, defoliation and pruning cause significant differences in regrowth characteristics of mopane, primarily due to the differential effect on the root/shoot ratio of the trees and the subsequent availability of resources per shoot. Despite these differences, however, the proportional investment towards tolerance and defence remained unaffected by either herbivory type. Neither regrowth nor defence took place at the expense of the other, as trees either produced compensatory regrowth with resistance levels equal to unbrowsed trees, or both a reduction in regrowth and defences. Furthermore, both types of response promote the replenishment of stored resources (Chapin 1980, Nowak \& Caldwell 1984) and therefore both enhance the plant's tolerance to herbivory. This, together with the prior pattern of resource allocation to storage organs, indicates how mopane trees are adapted to herbivory of either form (Coley et al. 1985, Stowe et al. 2000). Lastly, the differential effects of elephant and caterpillar herbivory, specifically the increased shoot and leaf length in response to pruning and the decrease in chemical defences after natural defoliation, could have a significant influence on further herbivory by each species. An intriguing possibility deserving further study is that elephants and mopane moths might select feeding patches in mopane woodland on the basis of prior herbivory by the other guild member.

\section{ACKNOWLEDGEMENTS}

We thank De Beers Consolidation Mines Ltd. and the staff of Venetia-Limpopo Nature Reserve for their assistance with this project. We also thank the numerous field assistants for their help with the data collection and the National Research Foundation (GUN 2053601 to Johan du Toit) for financial support. Thank you to Tim O'Connor for useful comments on an earlier draft.

\section{LITERATURE CITED}

ACOCKS, J. P. H. 1975. Veld types of South Africa. The Government Printer, Pretoria. 128 pp.

ALADOS, C. L., BARROSO, F. G. \& GARCÍA, L. 1997. Effects of early season defoliation on above-ground growth of Anthyllis cytisoides, a Mediterranean browse species. Journal of Arid Environments 37:269283.
ALBORN, H. T. \& TURLINGS, T. C. J. 1997. An elicitor of plant volatiles from beet armyworm oral secretion. Science 276:945-949.

ANTTONEN, S., PIISPANEN, R., OVASKA, J., MUTIKAINEN, P., SARANPÄÄ, P. \& VAPAAVUORI, E. 2002. Effects of defoliation on growth, biomass allocation, and wood properties of Betula pendula clones grown at different nutrient levels. Canadian Journal of Forestry Research 32:498-508.

AOAC 1990. Official methods of analysis. (Fifteenth edition). Association of Official Analytical Chemists, Inc., Arlington. 1230 pp.

BALDWIN, I. T. 1990. Herbivory simulations in ecological research. Trends in Ecology and Evolution 5:91-93.

BEN-SHAHAR, R. 1993. Patterns of elephant damage to vegetation in northern Botswana. Biological Conservation 65:249-256.

BERGMAN, M. 2002. Can saliva from moose, Alces alces, affect growth responses in the sallow, Salix caprea? Oikos 96:164-168.

BERGSTRÖM, R., SKARPE, C. \& DANELL, K. 2000. Plant responses and herbivory following simulated browsing and stem cutting of Combretum apiculatum. Journal of Vegetation Science 11:409-414.

BRYANT, J. P., HEITKÖNIG, I., KUROPAT, P. \&OWEN-SMITH, N. 1991. Effects of severe defoliation on the long-term resistance to insect attack and on leaf chemistry in six woody species of the Southern African savanna. The American Naturalist 137:50-63.

CHAPIN, F. S. 1980. Nutrient allocation and responses to defoliation in tundra plants. Arctic and Alpine Research 12:553-563.

COLEY, P.D., BRYANT, J.P.\& CHAPIN, F.S. 1985. Resource availability and plant antiherbivore defense. Science 230:895-899.

DANELL, K., BERGSTRÖM, R. \& EDENIUS, L. 1994. Effects of large mammalian browsers on architecture, biomass, and nutrients of woody plants. Journal of Mammalogy 75: 833-844.

DITLHOGO, M. K. 1996. Information on the biology and use of Imbrasia belina, and other edible moth species. Unpublished Ph.D. thesis, University of Manitoba, Winnipeg, Canada.

DUNCAN, A. J., HARTLEY, S. E. \& IASON, G. R. 1998. The effects of previous browsing damage on the morphology and chemical composition of Sitka spruce (Picea sitchensis) saplings and their subsequent susceptibility to browsing by red deer (Cervus elaphus). Forest Ecology and Management 103:57-67.

DU TOIT, J. T., BRYANT, J. P. \& FRISBY, K. 1990. Regrowth and palatability of Acacia shoots following pruning by African savanna browsers. Ecology 71:149-154.

FEENY, P. 1970. Seasonal changes in oak leaf tannins and nutrients as a cause of spring feeding by winter moth caterpillars. Ecology 55:565581.

FERREIRA, D., MARAIS, J. P. J. \& SLADE, D. 2003. Phytochemistry of the mopane, Colophospermum mopane. Phytochemistry 64:31-51.

GADD, M. E., YOUNG, T. P. \& PALMER, T. M. 2001. Effects of simulated shoot and leaf herbivory on vegetative growth and plant defence in Acacia drepanolobium. Oikos 92:515-521.

GASTON, K. J., CHOWN, S. L. \& STYLES, C. V. 1997. Changing size and changing enemies: the case of the mopane worm. Acta Oecologica 18:21-26.

HAGERMAN, A. E. 1995. Tannin handbook. Miami University, Ohio. $116 \mathrm{pp}$.

HENNING, A. C. \& WHITE, R. E. 1974. A study of the growth and distribution of Colophospermum mopane (Kirk ex Benth.) Kirk ex J. 
Léon.: the interaction of nitrogen, phosphorus and soil moisture stress. Proceedings of the Grassland Society of Southern Africa 9:5360.

HERMS, D. A. \& MATTSON, W. J. 1992. The dilemma of plants: to grow or defend. The Quarterly Review of Biology 67:283-335.

HJÄLTÉN, J. 2004. Simulating herbivory: problems and possibilities. Pp. 243-256 in Weisser, W. W. \& Siemann, E. (eds). Insects and ecosystem function. Springer-Verlag, Berlin.

HOBBS, N. T. 1996. Modification of ecosystems by ungulates. Journal of Wildlife Management 60:695-713.

HRABAR, H. 2005. Indirect interactions between elephants (Loxodonta africana) and mopane caterpillars (Imbrasia belina) through their shared food resource-mopane trees (Colophospermum mopane). Unpublished Ph.D. Dissertation, University of Pretoria, South Africa.

KAITANIEMI, P., NEUVONEN, S. \& NYYSSÖNEN, T. 1999. Effects of cumulative defoliation on growth, reproduction, and insect resistance in mountain birch. Ecology 80:524-532.

KATJIUA, M. L. J. \& WARD, D. 2006. Resistance and tolerance of Terminalia sericea trees to simulated herbivore damage under different soil and moisture conditions. Journal of Chemical Ecology 32:14311443.

KRAUSE, S. C. \& RAFFA, K. F. 1996. Differential growth and recovery rates following defoliation in related deciduous and evergreen tress. Trees 10:308-316.

LEHTILÄ, K., HAUKIOJA, E., KAITANIEMI, P. \& LAINE, K. A. 2000. Allocation of resources within mountain birch canopy after simulated winter browsing. Oikos 90:160-170.

LENNARTSSON, T., NILSSON, P. \& TUOMI, J. 1998. Induction of overcompensation in the field gentian, Gentianella campestris. Ecology 79:1061-1071.

LEWIS, D. M. 1986. Disturbance effects on elephant feeding: evidence for compression in Luangwa Valley, Zambia. African Journal of Ecology 24:227-241.

LEWIS, D. M. 1991. Observations of tree growth, woodland structure and elephant damage on Colophospermum mopane in Luangwa Valley, Zambia. African Journal of Ecology 29:207-221.

MACGREGOR, S. D. \& O'CONNOR, T. 2002. Patch dieback of Colophospermum mopane in a dysfunctional semi-arid savanna. Austral Ecology 27:385-395.

MASCHINSKI, J. \& WHITHAM, T. G. 1989. The continuum of plant responses to herbivory: the influence of plant association, nutrient availability, and timing. The American Naturalist 134:1-19.

MCCLOUD, E. S. \& BALDWIN, I. T. 1997. Herbivory and caterpillar regurgitants amplify the wound-induced increase in jasmonic acid but not nicotine in Nicotiana sylvestris. Planta 203:430-435.
MESSINA, F. J., DURHAM, S. L., RICHARDS, J. H. \& MCARTHUR, E. D. 2002. Trade-off between plant growth and defence? A comparison of sagebrush populations. Oecologia 131:43-51.

NOWAK, R. S. \& CALDWELL, M. M. 1984. A test for compensatory photosynthesis in the field: Implications for herbivory tolerance. Oecologia 61:311-318.

PICKER, M., GRIFFITHS, C. \& WEAVING, A. 2002. Field guide to insects of South Africa. Struik Publishers, South Africa. 444 pp.

PIENE, H., MACLEAN, D. A. \& LANDRY, M. 2003. Spruce budworm defoliation and growth loss in young balsam fir: relationships between volume growth and foliage weight in spaced and unspaced, defoliated and protected stands. Forest Ecology and Management 179:37-53.

PINHEY, E. C. G. 1972. Emperor moths of South and Central Africa. Struik Publishers, Cape Town. 150 pp.

REYNOLDS, B. C. \& HUNTER, M. D. 2001. Responses of soil respiration, soil nutrients, and litter decomposition to inputs from canopy herbivores. Soil Biology and Biochemistry 33:1641-1652.

ROOKE, T. 2003. Growth responses of a woody species to clipping and goat saliva. African Journal of Ecology 41:324-328.

ROOKE, T. \& BERGSTRÖM, R. 2007. Growth, chemical responses and herbivory after simulated leaf browsing in Combretum apiculatum. Plant Ecology 189:201-212.

SMALLIE, J. J. \& O'CONNOR, T. G. 2000. Elephant utilization of Colophospermum mopane: possible benefits of hedging. African Journal of Ecology 38:352-359.

SMIT, G.N.\&RETHMAN, N.F.G. 1998. Root biomass, depth distribution and relations with leaf biomass of Colophospermum mopane. South African Journal of Botany 64:38-43.

STOWE, K. A., MARQUIS, R. J., HOCHWENDER, C. G. \& SIMMS, E. L. 2000. The evolution of tolerance to consumer damage. Annual Review of Ecological Systematics 31:565-595.

STRAUSS, S. Y. 1991. Direct, indirect, and cumulative effects of three native herbivores on a shared host plant. Ecology 72:543-558.

TIFFIN, P. 2002. Competition and time of damage affect the pattern of selection acting on plant defence against herbivores. Ecology 83:1981-1990.

TIFFIN, P. \& INOUYE, B. D. 2000. Measuring tolerance to herbivory: accuracy and precision of estimates made using natural versus imposed damage. Evolution 54:1024-1029.

TIMBERLAKE, J. R. 1995. Colophospermum mopane: annotated bibliography and review. Zimbabwe Bulletin of Forestry Research 11:149.

ZAR, J. H. 1999. Biostatistical analysis. (Fourth edition). Prentice-Hall, Englewood Cliffs. 663 pp. 